The TQM Magazine, 1996, vol 8, issue 2, pages 26-31

\title{
Case Studies
}

\section{Is Management Commitment to Quality Just “A Given”?}

by Keith Goffin and Marek Szwejczewski

\begin{abstract}
Management at six factories in the UK which had received awards for their manufacturing excellence were interviewed about their TQM programmes. The aim of these interviews was to discuss the TQM initiatives and, in particular, to gauge the degree and nature of the management commitment required to make these successful. What emerged was an indication of the emphasis that managers must place on becoming personally involved if TQM is to be successful. Four common dimensions of management commitment were identified in the approaches seen across the six factories. These were the time and effort invested, emphasis on clear goals and organisations, management's manufacturing expertise, and a strong focus on employees (training and team work). Although this study is based only on six case studies, the topic of commitment is an important one with significant implications for management. It is also an area which is ripe for further, detailed investigation.
\end{abstract}

Keywords

UK manufacturing industry, management commitment to TQM

\section{INTRODUCTION}

commitment $\boldsymbol{n}$ committing; obligation or pledge, state of being involved Oxford English Dictionary

Open almost any management book on quality and you'll find lists of the prerequisites for successful TQM. One of the items always listed is "management commitment". But what does this mean in the context of quality and isn't it simply "a given" that management will be committed?

To investigate management commitment, the authors visited six award winning factories. These factories won the 1994 Best Factory Awards from Management Today - Cranfield School of Management, as part of the annual programme which publicly recognises and rewards manufacturing excellence in the UK. Although a factory does not necessarily have to use TQM to stand a chance of winning, all of the winners considered TQM as an important element in helping them achieve manufacturing excellence. Consequently, these top factories made ideal subjects for an investigation of management involvement in TQM. What emerged is 
that winning companies clearly do not treat management commitment as "a given"; on the contrary, management take quality very seriously.

\section{TQM and MANAGEMENT COMMITMENT}

TQM literature is rife with statements about the importance of management commitment. Examples are: "Top management commitment is recognised by all quality 'gurus' as being an essential precondition for the success of quality management" [1] and; "having recognised the need for Quality Improvement, the first objective is to secure management commitment" [2]. The focus on commitment can be traced to Crosby (his first step to quality improvement is "management commitment") and Deming.

Just as various authors have stressed the importance of management commitment to the success of TQM, others investigating TQM failures have cited lack of commitment as a root cause (e.g. [3]). A study of British management found that $18 \%$ of respondents saw lack of commitment as the cause of "major difficulty" [1]. A survey of European manufacturers showed many companies were using TQM superficially because of "a lack of management commitment" [4]. Other studies looking at TQM in, for instance, R\&D [5] and self-directed work teams [6] firmly identified lack of commitment as a major reason for failure.

Although recognition of management commitment is universal, few have tried to identify its essential components. One key paper, from Saraph et al [7] found that the most important aspects of commitment to be:-

- Participation of top management in quality programmes

- Specific quality goals

- Importance attached to quality in relation to costs and schedules

- Comprehensive quality planning

A recent paper in this magazine stated "management commitment is vital, but what exactly does this involve?" [8] and went on to suggest that active management involvement, willingness to implement change and a high priority for quality are all essential elements.

The authors decided to investigate whether the above, or similar components of commitment were present at six top UK factories.

\section{BACKGROUND - THE BEST FACTORY AWARDS}

The Best Factory Awards (BFA) programme not only recognises manufacturing excellence but also collects detailed information from industry for research and benchmarking purposes [9]. The awards are open to any UK manufacturer; factories must complete a detailed, confidential questionnaire covering, for example, performance data (e.g. delivery reliability) and management policy. Questionnaires are analysed and this results in a short-list of plants with high levels of performance, compared to the "norms" of their industry. A panel of judges visits short-listed companies and, in a day spent interviewing staff, verifies the performance data, probes the manufacturing strategy and checks on issues such as quality management. Each year six factories are awarded prizes; the selection process has been described in detail previously [9]. 


\section{LESSONS FROM THE 1994 WINNERS}

The BFA winning factories cover a wide range of markets and products - from, for example, doughnuts (Kitchen Range), to gearbox castings (Ryobi). Table 1 gives a brief description of each company and lists some of the key quality achievements.

Table 1: The Management Today ${ }^{1}$ - Cranfield School of Management 1994 Best Factory Award Winners.

\begin{tabular}{|c|c|c|c|}
\hline $\begin{array}{l}\text { Case } \\
\text { Study }\end{array}$ & Company & Type of Company / Sector & Examples of Results Achieved \\
\hline 1 & $\begin{array}{l}\text { European } \\
\text { Components, } \\
\text { Belfast, Northern } \\
\text { Ireland }\end{array}$ & $\begin{array}{l}\text { Manufacturer of seat belt } \\
\text { assemblies for motor vehicles / } 600 \\
\text { employees / Japanese owned }\end{array}$ & $\begin{array}{l}\text { Cell manufacturing and team work led to:- } \\
-13 \% \text { labour cost reduction } \\
-50 \% \text { floor space reduction } \\
-36 \% \text { quality improvement resulting from } \\
\text { poka yoke }\end{array}$ \\
\hline 2 & $\begin{array}{l}\text { Ryobi, } \\
\text { Carrickfergus, } \\
\text { Northern Ireland }\end{array}$ & $\begin{array}{l}\text { Aluminium die casting of car } \\
\text { gearboxes / } 45 \text { employees / } \\
\text { Japanese owned }\end{array}$ & $\begin{array}{l}\text { - Kaizen allowed the nominal capacity of } \\
\text { the plant of } 600 \text { castings per shift to be } \\
\text { increased to } 940 \\
\text { - Quality levels which set a standard for the } \\
\text { industry }\end{array}$ \\
\hline 3 & $\begin{array}{l}\text { Kitchen Range, } \\
\text { Peterborough }\end{array}$ & $\begin{array}{l}\text { Manufacture of doughnuts and fruit } \\
\text { pies / } 100 \text { employees / UK owned }\end{array}$ & $\begin{array}{l}\text { - Preventive maintenance yields a } \\
\text { downtime of only } 3 \% \\
\text { - Investment in the line was intended to } \\
\text { increase capacity by } 35 \% \text {, kaizen increased } \\
\text { this to } 50 \%\end{array}$ \\
\hline 4 & $\begin{array}{l}\text { Glaxo, Barnard } \\
\text { Castle, County } \\
\text { Durham }\end{array}$ & $\begin{array}{l}\text { Packaging of pharmaceuticals / } 500 \\
\text { employees / UK owned }\end{array}$ & $\begin{array}{l}\text {-Productivity increased by } 50 \% \\
\text {-Waste decreased by } 50 \% \\
\text {-On-time shipments from } 15 \% \text { to over } 90 \%\end{array}$ \\
\hline 5 & $\begin{array}{l}\text { Dexter Nonwovens, } \\
\text { Chirnside, } \\
\text { Berwickshire, } \\
\text { Scotland }\end{array}$ & $\begin{array}{l}\text { Manufacture of specialised papers / } \\
250 \text { employees / US owned }\end{array}$ & $\begin{array}{l}\text {-Lead times from } 12 \text { weeks in } 1989 \text { to } 3 \\
\text { weeks today } \\
\text {-Output is now } 2 \frac{1}{2} \text { times the original } \\
\text { supposed capacity } \\
\text {-Waste has been reduced from } 8.5 \% \text { to } 6 \% \\
\text {-Line downtime has decreased from } 7.5 \% \\
\text { to } 2.3 \%\end{array}$ \\
\hline 6 & $\begin{array}{l}\text { Design to } \\
\text { Distribution, } \\
\text { Kidsgrove, } \\
\text { Staffordshire }\end{array}$ & $\begin{array}{l}\text { JIT supply of high-volume printed } \\
\text { circuit boards / } 605 \text { employees / UK } \\
\text { owned }\end{array}$ & $\begin{array}{l}\text { - Lead times cut from } 40 \text { days to less than } 5 \\
\text { days } \\
\text { - High volume PCB's produced in an } \\
\text { elapsed time of between } 1 \text { and } 2 \text { hours, i.e. } \\
\text { start of the process to despatch to customer } \\
\text { - On-time delivery } 100 \% \text { of the time }\end{array}$ \\
\hline
\end{tabular}

1 Management Today is a widely-read UK monthly management magazine.

With such a wide range of industries, it might seem surprising that there are close similarities in the way management at these companies approach quality. However, there are common threads that run throughout the success stories of the six plants. Some of these are quantifiable, like the number and type of quality techniques used. Others, however, are qualitative - for instance the enthusiasm for quality at the winning factories. This could "be felt"; it came over strongly in discussions with not only management but also with production staff. Identifying the success factors in quality implementation is not an exact science. However, the authors attempted to answer the question "What is it about management commitment at these organisations that allowed them to achieve such impressive quality results?"

Many companies focus on techniques when they try to implement TQM. Although all of the winning companies use quality techniques, there is much more to successful TQM than this. In fact, observations and interviews identified four key aspects which led to successful TQM at the winning companies (Figure 1). These 
were the time and effort invested by management, whether clear goals and organisations were introduced, a passion for optimising production processes and a focus on staff (training and team-work). Each of these will be discussed and examples given.

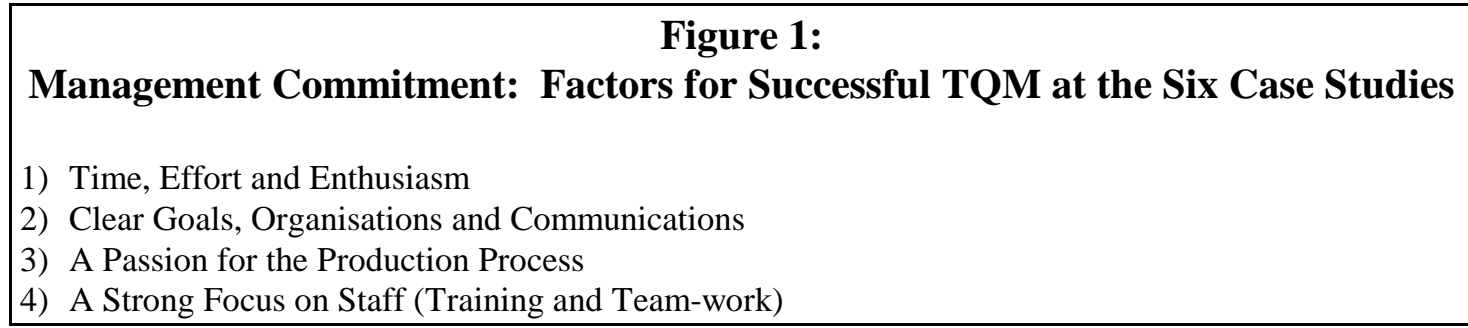

\section{1) Commitment $=$ Time, Effort and Enthusiasm}

The first common factor identified across the winning factories was the amount of management time, effort and enthusiasm invested in quality matters. The ability to delegate is obviously a vital management skill but it appears that in the case of quality, delegation is probably not the right approach. It takes time and persistence to overcome inertia, as shown by the experiences of the pharmaceutical company Glaxo at Barnard Castle, County Durham.

Glaxo had a very long struggle to persuade employees that continuous improvement programmes were really necessary. The company had been successful for many years in the pharmaceuticals market, largely through their R\&D strength. And quality levels were already high. "This made it hard to convince people that big improvements were necessary - in a profitable and growing market, cost reduction is not seen as a high priority" says manufacturing manager Ian McCubbin. However, Ian and his management team recognised that their market was becoming increasingly competitive and so, between 1987 and 1992, they launched four major quality initiatives. Some companies might have given up after one initiative and before any real results were achieved. However, management had set their sights high and so they persisted. Two sets of circumstances helped in achieving the essential level of awareness. Firstly, a new manager organised visits to other factories. Seeing the achievements of other factories galvanised Glaxo and the everyone became conscious of the need for higher quality. The second catalyst was management's "discovery" of Goldratt's "classic" book The Goal. Soon everyone was reading the fast-moving story of a manufacturing manager struggling against the odds to save his factory. Copies were made available to production employees and they eagerly read it. Subsequent kaizen projects have had $100 \%$ involvement of all employees. And this brought results - examples are $80 \%$ reduction in changeover times, $90 \%$ waste reduction and $50 \%$ reduction in lead times. Ian McCubbin does not know how much time he invested over the last five years in implementing quality. However, he does think it was time well spent.

At Dexter Nonwovens, a specialist paper manufacturer in Chirnside Scotland, quality required continuous management effort "over the last twelve years", says Ian Kenworthy, Quality Planning Manager. In 1983-6 the US parent company introduced TQM in response to increasing competition and the Chirnside plant followed suit in 1986 - Ian was sent to be trained on techniques such as kaizen and the work of Deming and Juran. He came back convinced of the value of TQM and trained all of 
his colleagues (everyone was trained: people from production, management and administration, including secretaries). The training marked the start of what has become a tradition at Dexter - significant quality improvements on a regular, never ending basis. (And Dexter have graphs going back to 1984 to prove it!) Management's constant focus on quality has led to impressive results, such as a reduction in lead time for specialised papers from 12 to 3 weeks. Even today General Manager Bill Paton is convinced that allocating time to quality is essential, saying "Normally it is the law of diminishing returns - but its not been so with us, we're still obtaining good results".

The examples demonstrate the effort required from management in successfully implementing TQM. This was the same at all the winning factories. And one thing is clear, when management shows its enthusiasm, this sends the clearest possible signal to staff on the importance of quality.

\section{2) Commitment $=$ Clear Goals, Organisations and Communications}

Quality initiatives often fail because goals are unclear, or there are barriers inherent in a company's organisational structure. Not so at the winning companies. They ensure everyone understands the goals and have, in some instances, made sweeping organisational changes to ensure nothing blocks progress.

European Components (ECC) in Belfast produce seat belt assemblies. They ensure that goals, including quality goals, are understood and receive sufficient attention throughout the company. ECC use Hoshin-type management planning and reporting (Hoshin means visionary goal in Japanese), in which each of the strategies set by management is broken down into its components and responsibility assigned to the appropriate departments. This guarantees that the relevant departments quickly focus on goals from above. To some, this might sound like everything is decided at the top. Not so, ECC encourage their line employees to set their own priorities for quality improvements. Consequently, ideas from both above and below converge to form a comprehensive quality policy. Organisational boundaries have also been addressed. For example, the responsibility for line maintenance was moved to the manufacturing cells. Cell teams now perform their own preventive maintenance and seldom need specialist support. ECC have put responsibilities where they belong and this has produced excellent results.

Clear management decisions, assigning responsibilities where they belong, were seen at all of the winning factories. For instance quality responsibility at Kitchen Range in Peterborough, manufacturer of doughnuts and fruit pies, lies with the line operators themselves. They call on support staff for the more complicated tests as need be. In addition, management have made sure that everyone knows the customer's - McDonalds Restaurants' - stringent quality requirements. Operators have the responsibility for the end-product and, if necessary, reject doughnuts that are not perfect (including rejection on purely aesthetic grounds). The quality requirements of the customer are not only clear to staff at Kitchen Range, but also are made clear to suppliers. For instance the quality of fruit used in pies is tightly specified and no variations are acceptable because they impact the end-product. Consistency in the texture ("chunkiness") and taste of pie fillings is critical to McDonalds. This imposes a significant discipline on Kitchen Range and, in turn, their suppliers. Meeting these goals can be difficult and "quite a lot of cultural change was required at one of our suppliers [to meet these goals]" explains Kitchen Range's Managing Director Simon Lebus. 
The examples show the importance of clear goals. Goals that are clearly communicated and assigned to an organisation whose structure supports rather than hinders their achievement.

\section{3) Commitment $=$ A Passion for the Production Process}

What makes a production process efficient? Which factors influence quality, costs and reproducibility? Must there be trade-offs? All of the winning companies have top managers who are passionately interested in these questions and have the drive to answer them. Management commitment must be built on a clear understanding of TQM [3] but, in a manufacturing scenario, it appears that managers who understand the technical details of processes also play a key role.

Ryobi's knowledge of their aluminium casting process demonstrates their attention to (manufacturing) detail. They mix a carefully measured amount of flux into the molten aluminium before casting gearbox housings. Many manufacturers do not use flux but Ryobi insist that it leads to higher quality and have detailed figures to prove it. So exact is their knowledge of the process that they can recognise when the quality of the purchased flux is insufficient. Locally purchased flux of the same specifications as that used in Japan gave sub-optimal results as revealed by monitored process variables. Investigation revealed that the flux was not exactly as specified. and so shipments of flux from Japan were organised, until the supplier solved the problem. Attention to detail has also helped Ryobi reach a quality level unmatched in the industry. One of the problems with poor gearbox castings is that, after machining, they may be porous to oil. Traditionally, car manufacturers who found porous castings sealed the castings' surfaces with chemicals and simply charged their suppliers for the cost of this treatment. However, Ryobi rejected this industry "norm" (where defects were never analysed) and defect castings are returned for a thorough analysis. Now through Ryobi's unique understanding of their process, very few defects occur - so few that it is a closely guarded figure that Ryobi do not share.

Design to Distribution in Kidsgrove (normally known as D2D) manufacture printed circuit boards (PCBs). Their managers thoroughly understand their production process. Through monitoring a wide range of process variables, they have developed a model which enables them to predict the reliability that a customer's design for a PCB will yield. Using this model they actively advise customers how to improve a design and how to reduce manufacturing costs in both the short and long-term. "All our customers want to see continuous cost reduction. They want to see a forward plan, and they want to know in advance what's going to come out of the costs - and when." says Jeff Sharrock, the plant's General Manager. The model is powerful enough to do this, to a degree of accuracy that wins customer loyalty.

The winning plants have managers who understand their manufacturing processes intimately. They do not see processes as fixed, instead they see constant opportunities for improvement.

\section{4) Commitment $=$ Strong Focus on Staff (Training and Team Work)}

It is a simple fact. Even if you recruit good people, if you do not develop their skills further then sooner, rather than later, you will have a problem. All of the winners continuously invest in training their staff. Awareness visits for staff to the US or Japan 
were seen as good investments, despite the costs involved. Benchmarking visits were seen as essential, as was having line employees meet customers. One of the most intriguing points from the top factories was how training had led to a high degree of team-work and enthusiasm for quality. Investment in staff training has paid a dividend for the winners - the key to their success is their people. It reminds the authors of the slogan seen in many of the factories of a top US computer manufacturer, known for its high quality "Systems make it possible but people make it happen".

Management at D2D perceive their continued success in a competitive market as critically dependent on the ability to learn faster than competitors. Consequently employees continuously need to learn new skills; on-the-job experience, learning from colleagues and actively seeking new knowledge are all aspects promoted in D2D's training philosophy. Each employee has a learning plan which is not simply a piece of paper written once and read never - at D2D it is a "living" document that is treated seriously and implemented.

The winning companies did not simply take "off the shelf" quality seminars. No, seminars were specifically tailored to fit the goals of the initiative. At European Components, management was directly involved in designing the 4 day quality seminar. Training Manager Christine McGowan, ensured a pragmatic approach employees chose actual problems which they wanted to solve using TQM methods. Christine attended all of the seminars and personally helps with kaizen projects. This approach led to quick "buy-in" from line employees and generated much enthusiasm. The value of this is seen in the energy staff put into applying one of the techniques covered in the training - poka yoke (Japanese for fail-safe). This technique is used to design manufacturing processes which prevent the possibility of mistakes and is an important consideration when producing complicated safety equipment like seat belts. Employees are now very adept at poka yoke and proudly tell visitors that quality levels are up $36 \%$ and that some of their ideas have been adopted in the Japanese parent plant.

One manager interviewed on team work was Hiroshi Urabe, a Japanese manufacturing manager at Ryobi, He is one of the world's experts on aluminium casting and some might think that such a specialist would only listen to the ideas of other experts. No, it is quite the contrary because Urabe-san really values the ideas that emerge from the team meetings saying, "Everybody has a good idea in his mind".

\section{Conclusions}

Much emphasis has been placed on the importance of management commitment in successful TQM. This study gives preliminary ideas of four key areas where management should concentrate with manufacturing TQM initiatives. Since many TQM programmes fail due to lack of commitment, the implication is that management should identify how they will address each of these four key areas before they start. Three factors are similar to those identified by other researchers [7] but one - the technical expertise in manufacturing shown by management - is new. Further research could focus on this area and give managers an even clearer indication of the practical steps they need to take to demonstrate commitment.

And how long is commitment required? The last word from the winning factories goes to Ian McCubbin from Glaxo. When asked whether, now that high quality has been achieved, he would reduce the amount of time he spends on quality issues, he replied; "No, because the moment we think that we've got it finally licked, that's the moment that we'll lose it - you can never take your foot off the accelerator". 


\section{Further Reading}

The UK's Department of Trade and Industry has published detailed case studies on the winning factories. Britain's Best Factories, Volume 2 can be obtained by either contacting the DTI in London (Tel. 0044-(0)171-5100144) or through the authors at Cranfield School of Management, Cranfield, UK (Tel. 0044-(0)-1234-751122).

\section{References}

1 Wilkinson, A., Redman, T. and Snape, E. "The problems with quality management - the view of managers: findings from an Institute of Management Survey", Total Quality Management, Vol. 5, No. 6, 1994, pp397-406.

2 Munro-Faure, L. and Munro-Faure, M. Implementing Total Quality Management, Pitman Publishing, London UK, 1992.

3 Marash, S.A. "The Key to TQM and World-Class Competitiveness - Part 1", Quality, Vol. 32, No. 9, September 1993, pp37-39.

4 Dale, B.G. and Lightburn, K. "Continuous Quality Improvement: Why Some Organisations Lack Commitment”, International Journal of Production Economics, Vol. 27, No. 1 1992, pp57-67.

5 May, C. and Pearson, A.W. "Total quality in R\&D”, Journal of General Management, Vol. 18, No. 3, Spring 1993, pp1-22.

6 Hitchcock, D. "Overcoming the Top Ten Self-Directed Team Stoppers", Journal for Quality and Participation, Vol. 15, No. 7, December 1992, pp4247.

7 Saraph, J.V., Benson, G. and Schroeder, R.G. "An Instrument for Measuring Critical Factors of Quality Management”, Decision Sciences, Vol. 20, No. 4, 1989, pp810-829.

8 Hollins, B. "TQM - Learning from Mistakes and Getting it Right Second Time”, The TQM Magazine, Vol. 7, No. 4, 1995, pp18-22.

9 New, C.C. and Szwejczewski, M. "Performance Measurement and the

Focused Factory: Empirical Evidence", International Journal of Operations \& Production Management, Vol. 15, No. 4, 1995, pp63-79.

\section{The Authors}

Keith Goffin and Marek Szwejczewski both work at Cranfield School of Management. Keith is a lecturer in operations management and Marek is a researcher in the field of manufacturing. Both have extensive experience in industry and are members of the Best Factory Awards team run by Professor Colin New. 